\title{
Organizational Elements Contributing to the Marketing Agility of a Firm
}

\author{
Geetha R, Divya Rekha
}

\begin{abstract}
Business establishments are enormously spending on competency intensification; more so for enhancement of marketing worth. There is a need to rationalize the lucidity and significance of such huge investments. Organizational resources play a fundamental role in boosting the marketing proficiency. But there are very few empirical studies to corroborate the significance of organizational attributes in increasing marketing dexterity of firms. Extant research is an effort to bridge this gap. It explores the role of organizational characteristics and human resource proficiencies contributing to enhancing marketing agility of the firm. Around 120 employees of a well-established manufacturing frim involved in the manufacture of sustainable products were surveyed using a structured questionnaire. Through an exploratory analysis the causative factors were identified and subsequently the opinion of the sample elements regarding the role of identified factors in enriching the marketing efficiency of their firm was sought. The data was analyzed using linear regression method and the results reflect that there is a significant correlation between organizational characteristics and the marketing dexterity but surprisingly the contribution of human resource capabilities to marketing adroitness is not considered as essential as organizational characteristics by the respondents.
\end{abstract}

Index Terms: Organizational Characteristics, Human Resource Capabilities, Marketing agility.

\section{INTRODUCTION}

Marketing Agility is a proactive ability to respond in a timely, effectively and sustainable way to dynamic market conditions and customer needs. There are very few empirical studies that have examined the implications of organizational factors on marketing agility in the manufacturing firms. Extant research examines the possible effects of organizational elements on marketing ability; elements under consideration are mainly classified into two categories - Organizational Characteristics and Human Resource Capabilities. Both Organizational Characteristics and Human Resource Capabilities are examined by considering 10 factors respectively. Organizational elements like - Vision, Mission, ,Strategy, structure, systems, policies, infrastructure brand image, size, growth rate, human resource capabilities are all considered for the study.

Revised Manuscript Received on July 5, 2019

Dr. Geetha, Professor \& HOD with the Department of MBA, DSATM,Opposite Art of Living International Center, Udayapurar Kanakapura Rd., Bangalore-560082 (e-mail: hodmba@dsatm.edu.in)

Divya Rekha, DSATM,Opposite Art of Living International Center, Udayapurar Kanakapura Rd., Bangalore

\section{LITERATURE REVIEW}

Brenda Gainer and Paulette Padanyi (2001): In their empirical study focused on the application of marketing concept to cultural organizations with emphasis on the correlation between market orientation and performance, have investigated and identified the elements that influence complex levels of market-driven activities that result in robust market driven cultures within organizations. Data was collected from organizations involved in art work located in two large cities in Canada, and the researchers analyzed the influence of such activities and ethos on the constructs used to assess performance using structural equations model. It was found that the firms that executed activities that were more market-driven in their market plan were more probable to cultivate an internal culture that is more market- sloping.

Fred Langerak, Henry S. J. Robben \& Erik Jan Hultink, (2004) have discussed in their paper on "The Impact of Market Orientation, Product Advantage, and Launch Proficiency on New Product Performance and Organizational Performance". Through a phone survey, 315 firms were identified. Around 211 (67.0 percent) proficient enumerators willing to coordinate with the exploration venture got a customized letter clarifying the reason for the examination. It was found that to an extent, Market-driven culture prompts high quality performance; the findings demonstrate that market centric strategy only secures product advantage and the proficiency in launch tactics but it does not have a significant impact on organizational performance.

Roger A. Layton (2011): In his study on "Marketing: Is management all that there is?" observes that the marketing systems influence the immediate social matrix in which they maneuver and the institutional and knowledge environs in which they are rooted. Through literature survey it was found that none of the earlier studies focused on the organizational factors like size, brand image, leadership, structure, systems, policies, processes, human resources capabilities and infrastructure as important to marketing dexterity of a firm. The current research work was undertaken to address this gap.

\section{STATEMENT OF PROBLEM}

Organizations are massively investing on capability enhancement, more so for enhancement of marketing efficiency. There is a need to 
justify the rational and worthiness behind such huge investments. Organizational resources play a pivotal role to upsurge the marketing efficiency.

But there are very few empirical studies to substantiate the significance of organizational factors contributing to the marketing agility. Current research is an effort to bridge this gap. It investigates the role of organizational characteristics and human resource capabilities in enhancing marketing agility of the firm

\section{SCOPE AND RATIONALE OF THE STUDY}

In order to analyze the implications of organizational factors on marketing agility, production and marketing units of Prakruti products private limited company located in Ankola and karwar taluks of Uttara kannada district, Karnataka state have been selected as sample units. The scope of the study is confined to top level, middle level and entry level employees of marketing and production unit of Prakruti products Pvt., Ltd. around 120 employees of Prakruti products Pvt., Ltd. were surveyed to elicit responses for the stated study. The dimensions considered under the scope of the study include:

Organization Characteristics:

- Size of the Company

- Brand Value of the Company

- Value Based and Ethical Leadership

- Well specified Vision, Mission and Objectives

- Well Defined Organization Structure

- Product Design and Development Strategies

- Quality Policy of the Company

- Research and Innovation Capabilities

- Well Built Infrastructure

- Stream-lined Systems and Processes

Human Resource Skills and Capabilities

- Relational Capabilities

- Technical Skills and Capabilities

- Product Design and Development Capabilities

- Sales Skills and Capabilities

- Marketing and Distribution Capabilities

- Strategic Skills and Capabilities

- Organizing Skills and Capabilities

- Continuous Improvement and Learning capabilities

- Capability to Adapt to the Dynamic Changes in the Business Environment

- Communication and Persuasive Skills and Capabilities

\section{RESEARCH OBJECTIVES}

[1]. Identification of the organizational elements and attributes determining the human resource capabilities that contribute to the enhancement of the marketing agility of the firm.

[2]. To examine the degree to which organization characteristics contribute to marketing Dexterity of the firm.

[3]. To analyze the extent to which human resource capabilities influence marketing efficiency of the firm.

[4]. To suggest measures for enhancement of marketing efficiency based on findings of the study.

\section{RESEARCH FRAMEWORK}

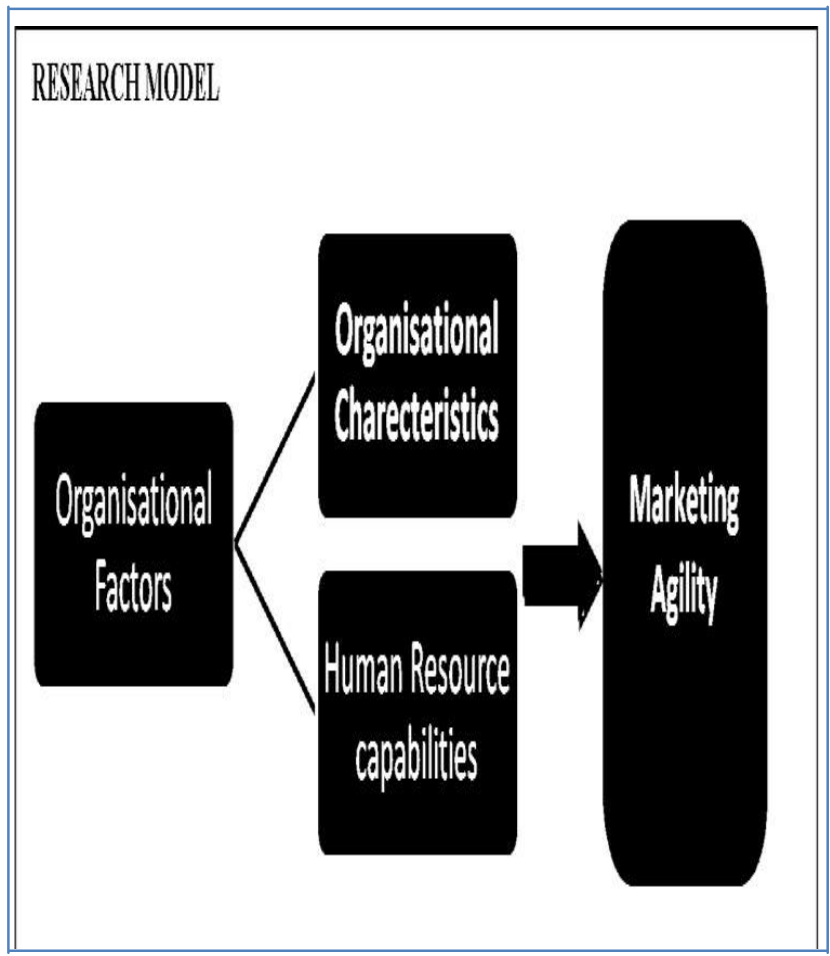

Fig-1: Source: Developed by authors

\section{RESEARCH METHODOLOGY}

Descriptive and Exploratory research designs were adopted in present study. Preliminary exploratory survey was conducted to identify the concept, dimensions and constructs of the study. Subsequent to that by adopting descriptive design primary data was collected using questionnaire as research instrument. Secondary data was collected from books, journals database repositories likeGoogle scholar, EBSCO, J-Gate etc. and through other resources like newspaper and web search. Simple random sampling method and probability technique was adopted for collecting primary data from sample elements that comprised of 250 employees of Prakruti Products Private Limited.

Mathematical, statistical and graphical tool have been applied to analyze and interpret the data. Percentage analysis frequency distribution

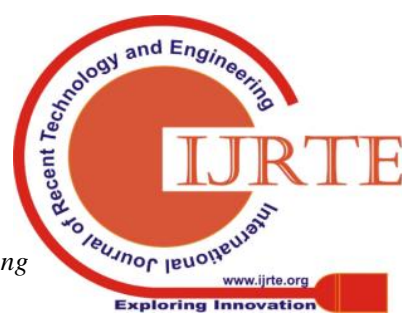


table, reliability analysis, and regression tools have been used to analyze the data. constructs since the value $0.778 \& 0.816$ is over the statistically viable limit set at 0.70 .

\section{ANALYSIS AND INTERPRETATION OF DATA}

Table 1: Demographic details of the respondents

\section{HYPOTHESIS}

Hypothesis-1: Ho1: Cetirus Paribus, there is no significant correlation between Organizational Factors and Marketing Agility.

\begin{tabular}{|c|c|c|c|}
\hline $\begin{array}{l}\text { Demographic } \\
\text { Characteristics }\end{array}$ & Categories & Frequency & Percentage \\
\hline $\begin{array}{l}\text { Gender wise } \\
\text { Classification }\end{array}$ & $\begin{array}{l}\text { Male } \\
\text { Female }\end{array}$ & $\begin{array}{l}99 \\
21\end{array}$ & $\begin{array}{l}81.8 \\
17.4\end{array}$ \\
\hline $\begin{array}{l}\text { Age wise } \\
\text { Distribution }\end{array}$ & $\begin{array}{l}<25 \\
25-35 \\
36-45 \\
46-55 \\
>55\end{array}$ & $\begin{array}{l}19 \\
52 \\
33 \\
14 \\
2\end{array}$ & $\begin{array}{l}15.8 \\
43.3 \\
27.5 \\
11.7 \\
1.7\end{array}$ \\
\hline $\begin{array}{l}\text { Department wise } \\
\text { Classification }\end{array}$ & $\begin{array}{l}\text { Production } \\
\text { HR } \\
\text { Marketing } \\
\text { Finance } \\
\text { Any other } \\
\text { Specify }\end{array}$ & $\begin{array}{l}37 \\
21 \\
19 \\
6 \\
37\end{array}$ & $\begin{array}{l}30.8 \\
17.5 \\
15.8 \\
5.0 \\
30.8\end{array}$ \\
\hline $\begin{array}{l}\text { Classification } \\
\text { Based on } \\
\text { Designation }\end{array}$ & $\begin{array}{l}\text { Top Level } \\
\text { Middle Level } \\
\text { Entry Level }\end{array}$ & $\begin{array}{l}15 \\
62 \\
41\end{array}$ & $\begin{array}{l}12.5 \\
51.7 \\
34.2\end{array}$ \\
\hline $\begin{array}{l}\text { Classification } \\
\text { Based } \\
\text { On Experience }\end{array}$ & $\begin{array}{l}<1 \\
1-4 \\
5-9 \\
10-15 \\
>15\end{array}$ & $\begin{array}{l}28 \\
48 \\
38 \\
5 \\
2\end{array}$ & $\begin{array}{l}23.4 \\
39.6 \\
31.4 \\
4.3 \\
1.3\end{array}$ \\
\hline $\begin{array}{l}\text { Classification } \\
\text { Based on Annual } \\
\text { Income }\end{array}$ & $\begin{array}{l}1-3 \text { (lakhs) } \\
4-6 \\
7-10 \\
10-15 \\
>15\end{array}$ & $\begin{array}{l}45 \\
55 \\
13 \\
4 \\
3\end{array}$ & $\begin{array}{l}37.5 \\
45.8 \\
10.8 \\
3.3 \\
2.5\end{array}$ \\
\hline$N=120$ & & & \\
\hline
\end{tabular}

Table-1 portrays a snapshot of the demographic details of the respondents surveyed. Survey details reflect that $81.8 \%$ of the sample elements questioned comprised of Men and the remaining of them comprised of women. Nearly $43.3 \%$ of the respondents belong to an age group of 25 to 35 years and were mostly from Rural and Semi Urban area of Ankola and Karwar Taluks of Uttara Kannada District. Nearly 51.7\% of the employees were middle level, $4-5.8 \%$ earn close to a range of four to six lakhs of annual income. Classification based on gender, age, designation, experience and annual income were considered to examine if opinion differs across categories of respondents defined by their demographic features.

\section{Reliability Test}

Table 2: Consistency Statistics of Elements

\begin{tabular}{|c|c|}
\hline \multicolumn{2}{|l|}{ Consistency Statistics } \\
\hline Value of Cronbach's Alpha & No. of Factors \\
\hline 0.778 & 9 \\
\hline 0.816 & 10 \\
\hline
\end{tabular}

Cronbach's test was run on SPSS to examine the steadfastness of the research instrument used for data collection. The Cronbach's alpha for- nine Organizational factors influencing the Marketing Agility of the firm is 0.778 and for Human Resource Capability factor it is 0.816 . This indicates an acceptable level of inner stability among the

Table 3a: Model Summary

\begin{tabular}{|c|c|c|c|c|}
\hline \multicolumn{4}{|c|}{ Summary of the Mode } & $N=120$ \\
\hline $\begin{array}{l}\text { Model } \\
\text { Summa } \\
\text { ry }\end{array}$ & R-Value & $\begin{array}{l}\text { R Square } \\
\text { Value }\end{array}$ & $\begin{array}{l}\text { Adjusted R } \\
\text { Square-Va } \\
\text { lue }\end{array}$ & $\begin{array}{l}\text { Std. Error of } \\
\text { the Estimate } \\
\text { Score }\end{array}$ \\
\hline 1 & $0.173^{a}$ & 0.030 & 0.022 & 1.032 \\
\hline
\end{tabular}

Table 3b: ANOVA

\begin{tabular}{|c|c|c|c|c|c|c|}
\hline \multicolumn{7}{|c|}{ Coefficients $\mathbf{N}=120$} \\
\hline \multirow{2}{*}{\multicolumn{2}{|c|}{ Model Summary }} & \multicolumn{2}{|c|}{$\begin{array}{l}\text { Coefficient } \\
\text { Values(Unstanda } \\
\text { rdized }\end{array}$} & \multirow{2}{*}{$\begin{array}{l}\begin{array}{l}\text { Coefficient } \\
\text { Values(Standa } \\
\text { rdized }\end{array} \\
\text { Beta Value } \\
\end{array}$} & \multirow[t]{2}{*}{$t$} & \multirow[t]{2}{*}{$\begin{array}{l}\text { Sign. } \\
\text {. }\end{array}$} \\
\hline & & B-Score & $\begin{array}{l}\text { Sd. } \\
\text { Error }\end{array}$ & & & \\
\hline \multirow[t]{2}{*}{1} & Cohstant Value & 4.883 & .592 & & 8.244 & .000 \\
\hline & $\begin{array}{l}\text { Well Specified } \\
\text { Vision, Mission } \\
\text { and Objectives }\end{array}$ & .275 & .144 & 173 & 1.910 & .059 \\
\hline
\end{tabular}

$@ \alpha=10 \%$

The results of the regression analysis are shown in Table-3 a, b \& C. The result does not support the hypothesis-1stated above and hence null hypothesis is not accepted. The standard beta coefficient is 0.173 . There is a direct correlation between the dependent and independent variable. The positive relation between the dependent and independent variable is significant at $90 \%$ percent confidence level as indicated by $(\mathrm{P}<0.1)$.

Hypothesis-2: Ho2: Cetirus Paribus, there is no significant correlation between Human Resource Capabilities and Marketing Agility

Table 3c: ANOVA

\begin{tabular}{|l|c|c|c|c|}
\hline \multicolumn{5}{|l|}{ Summary of the Model } \\
\hline $\begin{array}{l}\text { Details of } \\
\text { Model }\end{array}$ & R Value & $\begin{array}{l}\text { Value of R } \\
\text { Square }\end{array}$ & $\begin{array}{l}\text { Value of } \\
\text { Adjusted R } \\
\text { Square }\end{array}$ & $\begin{array}{l}\text { Std. Error of } \\
\text { the Estimate }\end{array}$ \\
\hline 1 & $.058^{\mathrm{a}}$ & .003 & -.005 & .888 \\
\hline \multicolumn{5}{|l|}{ a. Predictor Factors: (Constant), Sales Skills and Capabilities } \\
\hline
\end{tabular}

@ $\alpha=10 \%$ Table 4a: Model Summary 
Table 4 b: ANOVA

\begin{tabular}{|c|c|c|c|c|c|}
\hline ANOVA $^{a}$ & $=120$ & & & & \\
\hline $\begin{array}{l}\text { Details of } \\
\text { Model }\end{array}$ & $\begin{array}{l}\text { Squares } \\
\text { Summed } \\
\text { Up }\end{array}$ & $\begin{array}{c}\text { DF } \\
\text { Value }\end{array}$ & $\begin{array}{l}\text { Square } \\
\text { d Mean }\end{array}$ & F-Score & $\begin{array}{r}\text { Signi } \\
\mathbf{f .}\end{array}$ \\
\hline 1 Regression & .318 & 1 & .318 & $\begin{array}{c}.40 \\
4\end{array}$ & $.526^{\mathrm{b}}$ \\
\hline Residual & 92.982 & 118 & .788 & & \\
\hline Total & 93.300 & 119 & & & \\
\hline \multicolumn{6}{|c|}{$\begin{array}{l}\text { a. Dependent Variable: Influence of Human Resource } \\
\text { Capability on } \\
\text { marketing agility }\end{array}$} \\
\hline \multicolumn{6}{|c|}{ b. Predictors: (Constant), Sales Skills and Capabilities } \\
\hline
\end{tabular}

Table 4 c: Regression

\begin{tabular}{|c|c|c|c|c|c|}
\hline \multicolumn{4}{|l|}{ Coefficients } & \multicolumn{2}{|r|}{$N=120$} \\
\hline \multirow[t]{2}{*}{$\begin{array}{l}\text { Model } \\
\text { Summary }\end{array}$} & \multicolumn{2}{|c|}{$\begin{array}{l}\text { Coefficient(Un } \\
\text { standardized }\end{array}$} & \multirow{2}{*}{ 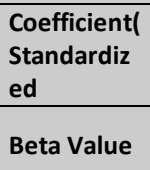 } & \multirow[t]{2}{*}{$\begin{array}{l}\text { t-Valu } \\
\text { e }\end{array}$} & \multirow[t]{2}{*}{ Sign. } \\
\hline & B Value & $\begin{array}{l}\text { Stand. } \\
\text { Error }\end{array}$ & & & \\
\hline $\begin{array}{l}1 \text { Constant } \\
\text { Value }\end{array}$ & 4.149 & .476 & & 8.718 & .000 \\
\hline $\begin{array}{l}\text { Sales } \\
\text { Skills } \\
\text { and } \\
\text { Capabilit } \\
\text { ies }\end{array}$ & -.076 & .119 & -.058 & -.635 & .526 \\
\hline \multicolumn{6}{|c|}{$\begin{array}{l}\text { a. Dependent Variable: Influence of Human Resource Capability on } \\
\text { marketing agility }\end{array}$} \\
\hline
\end{tabular}

Table-4, sections a, b and c depict the outcomes of the statistical investigation. The upshots indicate that the second hypothesis mentioned may be accepted. The beta coefficient value is observed to be -0.058 . The level of significance is 0.526 for the independent element sales skills and capabilities indicating that there is significant association between the HR competencies and Marketing Agility. The association between the dependent element and independent element is statistically significant at $10 \%$ percent significance as indicated by $(\mathrm{P}<0.1)$.

\section{MANAGERIAL IMPLICATIONS AND LIMITATIONS}

Managers of manufacturing entities may use research results to gain insights about the organizational attributes contributing to their marketing efficacy. It facilitates them to understand the various factors that determine their sales capabilities. This in turn will help them in the formulation and implementation of appropriate strategies to augment their marketing efficiencies by strengthening their internal capabilities and resources.

\section{FINDINGS}

[1].Employees of the organization totally agreed on quality as an important attribute contributing to the enhancement of marketing proficiency.
[2].Nearly $68 \%$ of the responses mentioned the role of extant leadership style enhances selling efficacy.

[3].Many employee expressed Brand reputation and Brand Value of the company as important to consolidate firm's promotion capabilities.

[4].Close to $70 \%$ of the employees stated that the Strategic skills and capabilities are of priority to improve the promotion and sales capabilities.

[5].Survey outcomes indicate that growth rate in terms of profitability derived from sales assumes a remarkable role in augmenting the sales and distribution competence of the firm.

[6].Sales factors like the marketing skills, distribution skills and sales strategy and sales volume are not considered as priority for boosting marketing capabilities and marketing efficiency of the firm.

\section{RECOMMENDATIONS}

[1].By hiring experienced workforce and executives, firm will be able to strengthen their dexterity and capabilities.

[2]. As Prakruti Products Pvt. Ltd. Male dominated company so the company should recruit female employees to ensure gender inclusivity

[3].Around $28 \%$ of the workforce surveyed indicated the quality of the product as moderately good but not superior. Keeping this in perspective, the firm may focus on augmenting the product quality to increase sales.

[4]. Salesforce of the firm may be provided need based training to hone their proficiency in sales and marketing.

[5]. In order to bolster the market value of the firm, the managing crew may engage additional trained workforce.

[6]. Technology up gradation may be given greater attention since it plays a catalytic role in building the marketing capabilities of business establishments.

\section{CONCLUSION}

The Ten organizational factors included under the purview of the extant research to examine their possible implication on the marketing agility of the firm seem to have a significant influence on the promotion, selling and distribution capabilities. The elements identified for research have enabled the firm to in positioning favorably in the market. 
However, since the human resources within the enterprise are not proficient enough adequate training and coaching can help in increasing the proficiencies of the people. Suitable strategies may be formulated to boost marketing adeptness, as several personnel voiced concern about scanty management involvement. Overall evaluation indicates that organizational features are contributing significantly to the marketing efficiency. But manpower capabilities need a fillip so that they become more active in their roles and contribute to organizational growth

\section{REFERENCES}

1. Gainer, B., and Padanyi, P. (2001). The utilization of the promoting idea to social associations: An observational investigation of belief system and practice. In Proceedings AIMAC 2001, sixth International Conference on Arts and Cultural Management (pp. 78-79).

2. Layton, R. A. (2011). Advertising: is the executives all that there is?. Diary of Historical Research in Marketing, 3(2), 194-213.

3. Langerak, F., Hultink, E. J., and Robben, H. S. (2004). The effect of market introduction, item favorable position, and dispatch capability on new item execution and authoritative execution. Diary of item development the executives, 21(2), 79-94.

4. R., Geetha, Explicating the Interaction between Marketing Dexterity and Constitutive Elements of an Enterprise (March 1, 2015). TIJARCM, Vol.1 Issue 1, March 2015, ISSN 2395-0854

\section{AUTHORS PROFILE}

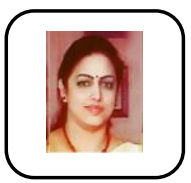

Dr Geetha has a career spanning 14 years as an academician and has had brief stints as an entrepreneur with Zee Network. She is specialized in Leadership Development, Strategic Talent Management, Knowledge Management, International Human Resource Management, OB, International Business, Managerial Economics and Macroeconomics. Her unique abilities and strengths as a professional are reflected by an exclusive professional experience in analytical skills, mentoring, lecturing, academic publishing, editing, research and content writing. She is a strong education professional with a PhD focused in Digital HRM from the University of Mysore. She has 26 research publications to her credit and is acknowledged among the top $10 \%$ of the authors on Social Science Research Network She has sequentially won 5 best paper awards in various international and national conferences hosted by reputed B-Schools. She has served as a track Chair and panelist at International Conferences held in various Institutions and is is also involved in other academic associations as a member of Board of Examination/Board of Studies and has delivered guest talks in reputed B-schools on Corporate Economics and Current trends in technology and Management. She served as Managing Editor of TIJARCM, International Journal with ISSN and brought out 2 Volumes and 4 issues of the journal at RJSIMS. Besides, she is editorial member of Samyoga, International Journal of Management and ARSEAM,. She has organized and coordinated several FDPs, workshops, seminars, symposia and management fests at Institutions served.

Dr. Geetha served as a Peer reviewer for international journals - Canadian Journal of Management and Sustainability, ARSEAM and Chronicle. She is a recognized research supervisor of VTU and has guided $4 \mathrm{PhD}$ research scholars, During the span of her career as an academician she has guided close to 300 projects Management graduates of various Universities. Besides these, she is also a member of the professional associations and NGOs like NHRDN, SHRM, and SRCM and several others.

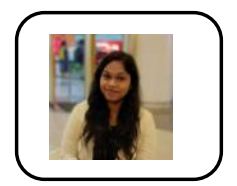

Ms. Divya Rekha graduated in Management from Dayananda Sagar Academy of Technology and Management which is affiliated to Visvesvaraya Technological University, Belagavi- Karnataka. She is currently employed as an HR Associate with Amazon India on contract basis where she is responsible for efficient, satisfactory and optimal operations. Divya's areas of interest include- Consumer Behaviour, Market research, Marketing Agility and Human Resource Management Trends in the millennium. She is actively involved in research and publications. Recently she published a research paper in the proceedings of the National Conference- on Convergence of Science, Technology and Management-2019. She also presented her empirical research paper at a conference organized by
IFIM. She has a Bachelor's Degree in Engineering from the Visvesvaraya Technological University Belagavi.

During her tenure as a student at DSATM, she was actively involved in organizing and coordinating various HR- Club activities. Besides, she also has an aptitude for research and publication. Divya is self-driven and independent. Apart from her MBA-curriculum bound courses, she has also completed several certified supplementary enrichment courses in- Digital Marketing, Entrepreneurship Development, Professional Development, Advanced Excel, Aptitude Training, Innovation and Leadership Training and others. She was one of the Chief coordinators of HR -Event of Aavartan-18 and 19- Industry sponsored Management Fest hosted at DSATM. Her hobbies include reading, drawing, listening to music and cooking. 